\title{
Contemporary China's Rural Landownership with Reference to Antony M. Honoré's Concept of Ownership
}

\section{Gaofeng Meng}

Gaofeng Meng is a doctoral student in School of Law, University of Glasgow. The author is grateful for useful and insightful comments from Christopher Brown, the editor of the Journal of Economic Issue, and one anonymous referee. The idea for this article was inspired by Paddy Ireland. An early draft of the article was presented at Tilburg University's School of Law, Netherlands, in April 2014, and then to the Glasgow University's School of Law, Scotland. Emilios Christodoulidis and H.K. Lindahl's detailed guidance is highly appreciated. The author is deeply indebted to David McLellan for all his help, as well as to Pauline Walters, Brain Kelly, Mr. and Mrs. de Groot, Noel Peacock, Timothy Noel Peacock, Su Bian, Jose Manuel Fernandez, Sindhyar Talpur, and Taric Olcay for their helpful advice and comments. I appreciate highly Fatme Myuhtar-May's proof-reading.

\begin{abstract}
This article analyses the property rights that Chinese peasants have under the present Household Responsibility System (HRS) using Antony M. Honoré's work on ownership, especially his analysis of eleven standard incidents of the full liberal concept of ownership. It confirms Honoré's insight that these standard incidents can be divided among two or more persons, and thus there are different types of property rights which are variants and alternatives to the liberal type of property rights. This article also confirms that the Chinese land system is a real alternative to the full liberal concept of ownership. The current Chinese land system is alleged to be "unclear and insecure" because it is not the kind of private ownership that neoliberals champion. In the tradition of the "bundle of rights" theory, it is helpful to use Honoré's concept of ownership, rather than Harold Demsetz's type of property rights, to understand the current Chinese system.
\end{abstract}

Keywords: eleven ingredients of ownership, household responsibility system, split ownership

JEL Classification Codes: E60, P260, O130, Q120, Q180.

In this article, I seek to contribute to the literature on rural land ownership in China under the Household Responsibility System (HRS), and on one kind of "bundle of property rights" theory - Antony M. Honoré's concept of ownership. HRS has been a successful, effective, and sustainable institutional arrangement in China for more than three decades since it was introduced between 1979 and 1983. It was developed initially by land users and supported by local government leaders. Because it was so successful, it was promoted by China's central government leadership to become a national institutional arrangement (Chen 1985; EBCAY 1980-1984; Wu 2002; Zhang 2002). From the perspective of the Chinese peasants, it was the preferred institutional choice (Kelliher 1992; Lin 1987, 1988, 1992; Ma and Lin 1998; Wu 1998; Zhou 1996). However, it was by no means politically neutral because the Chinese Communist Party clearly played a crucial role in the early 1980s in extending it nationwide (Bramall 2000; $\mathrm{Xu}$ 2013). 
The introduction of HRS (1979/1983) contributed to the increase of output growth and agricultural productivity by the productive use of inputs (Lin 1989, 1992; McMillan et al., 1989; Wen 1989). Of course, other reforms - including an increase in state procurement prices (Bramall 2000), market prices, an increase in labor productivity, and the application of chemical fertilizer - also contributed to growth during this period. This also improved peasants' incentives to adopt new technology, thus speeding up the modernization of agriculture in China (Lin 1991). More importantly, the peasants obtained more economic independence and greater freedom, such as having a choice between work and leisure, managing their land, and controlling of their residuary income (Johnson 1990, ch.8). Undoubtedly, this property rights arrangement has contributed to economic growth in rural and other sectors of the economy (Bramall 2004; Mead 2003; Yao 1999; Zhang and Donaldson 2013). It has also played a very important role in eliminating rural poverty (Dollar 2007; Ravallion 2009; Whyte 1986). It is the starting point for the take-off of the Chinese economy that has, on the whole, maintained a high rate of growth (Hodgson and Huang 2013). Many analysts have predicted that China would maintain a rate growth of around 7.0 percent until 2040 (Chow and Li 2002; Fogel 2010; Song, Storesletten and Zilibotti 2011).

However, it is this successful and sustainable institutional arrangement that has been criticized as the root of a series of socio-economic problems with HRS (Dong 1996; Zhang and Donaldson 2013). Property rights, especially collective rural landownership, have been criticized as "ill-defined" and "unclear" (Fewsmith 2008; World Bank 1990, 149). For example, Ling Zhu and Zhongyi Jiang $(1993,447)$ claimed that "no one in the community is a real owner of land," and referred to the "vagueness in the land ownership." Peter Nolan $(1993,74)$ extended this view and concluded that, "[i]n all important areas of the economy, transparent, legally protected individual property rights were the exception, not the rule. Public ownership with confused property rights was the norm." Peter Ho $(2001,2005)$ has claimed that there is no "clarity on state ownership," but rather "a deliberately vague definition of collective ownership." Other scholars have asserted that the great issue in HRS came as a result of insecurity. For example, Geoffery M. Hodgson and Kainan Huang $(2013,611)$ assert that "[u]se rights are sometimes curtailed through expropriations or compulsory purchase with little compensation. The greater problems lie with the security of some property rights, rather than with their vagueness."

Problems notwithstanding, this "half way house" performs quite well. As Nolan (1993) pointed out, this phenomenon puzzled many mainstream economists and policy analysts. Facing this puzzle, some writers have attempted to modify their beliefs and assumptions. For example, Jean C. Oi (1999, 194-195), stated that "those who maintain that individual private property rights provide the best basis for growth may ultimately be proved right ... The point is that privatization does not have a monopoly on the capacity to generate growth ... [T]he usual description of the type of property rights deemed necessary for effective growth, need not have a fixed meaning." Even Douglass North has modified his basic assumptions by stressing the importance of cultural heritage (2003, 10, note 3). Others continue to argue that the collective ownership under HRS in China can only produce short-term gains that will damage long-term performance. Such authors also predict the collapse of the Chinese economy, unless the full private property rights were imposed on the nation by the government (Chang 2001; Pei 2006; Shirk 2007; Wang and Hu 1999).

How do we explain this puzzle? At the heart of it, scholars like North (1981, 1990, 2005) (also Alchian and Demsetz 1973; Coase 1960; North and Thomas 1973) believe that only private ownership is clear and secure, and only pure private ownership can promote economic growth. Chinese land ownership has not been pure private ownership, whether in a historical context or compared to other forms of ownership currently existing in western society. It is neither pure 
public ownership like that of the communal system under Mao's regime, nor is it similar to that of the former Soviet Union or Eastern European countries, (those criticized by János Kornai 1992). North and others have attempted to re-conceptualize Chinese reality to fit into this theory, and such attempts impose formalized assumptions that distort the relationship between reality and theory (Kay 1997). As Elinor Ostrom $(2010,642)$ noted, they "try to fit the world into simple models and to criticize institutional arrangements that did not fit."

HRS is neither public, nor private ownership. Rather, it is a form of collective ownership combined with individual use rights. It is helpful here to mention the "tragedy of the commons" theme in order to understand the debate regarding HRS - a concept that has been a prominent feature of scholarly discussion since1950s. H. Scott Gordon $(1954,124)$ identified the problem as "everybody's property is nobody's property," while Garrett Hardin $(1968,1244)$, invited the reader to image a pasture "open to all."

Therein is the tragedy. Each man is locked into a system that compels him/her to increase his/her herd without limit in a world that is limited. Ruin is the destination toward which all men rush, each pursuing his/her own best interest in a society that believes in the freedom of the commons.

In order to solve this problem, Hardin $(1978,314)$ called for either "a private enterprise system," or "socialism." Some scholars have argued that the reordering of the state as a "Leviathan," which controls and regulates natural resources, was the only way to solve the "tragedy of the commons" (Carruthers and Stoner 1981; Ehrenfeld 1972; Heilbroner 1974; Ophuls 1973, 1977). Alternative academic positions have included calling for the imposition of private property rights (Johnson 1972; Smith 1981; Welch 1983), or for the combination of "state control" and "privatization" (Sinn 1984, 249).

This debate has also called into question the Chinese system. For example, Zhu and Jiang (1993, 455) claim that, "[w]ithout specific legislation to clarify the rights and obligations of both owners and users of land, it is impossible to protect farmland from misuse, despite the fact that land is extremely scarce." The debate has also been advanced following the falling rate of growth after 1984, and prompting further alternative proposals by commentators. Scholars like R.L. Prosterman and T.M. Hanstad (1990) recommended a program of land privatization via land titling or registration. Others like Qiren Zhou (1991) and Haidong Wang (1989) called for a complete separation of private user rights from public ownership of land.

In analyzing the Chinese land system, Peter Ho (2001, 401) and Oi (1991, 194-195) discuss Demsetz's "bundle of rights" theory that he developed in such articles as "Toward a Theory of Property Rights" (1967) and "The Structure of Ownership and the Theory of the Firm" (1983). It would be inappropriate to use the notion of ownership from these works as a basis for analyzing HRS, which is not equivalent to the pure private ownership advocated by Demsetz. As Ostrom notes, Demsetz as a scholar is representative of those "calling for the imposition of private property rights when even resources are owned in common. (Ostrom, 1990, 12)" He is also among those commentators that equate private ownership with capitalism and public ownership with socialism (see Demsetz 2002). I submit that if we want to use the "bundle of rights" theory to analyze the current Chinese rural land system, Honoré provides a better and more fruitful starting point to do so in his essay, Ownership (1961).

Following the tradition of "bundle of rights," initiated by Wesley Hohfeld in his celebrated essays "Some Fundamental Legal Conceptions as Applied in Legal Reasoning" (1913) and "Fundamental Legal Conceptions as Applied in Judicial Reasoning" (1917) (Alexander 1997; Baron 2014; Dagan 2003; Heller 1999; Johnson 2007; Merrill and Smith 2001; Mossoff 2009; Munzer 1990), Honoré develops a classical analysis of ownership. He recognizes that there are different types of property rights. Taking the liberal concept of ownership as the basic model, he 
sets out the eleven ingredients of full liberal property rights, conceptualizing these standard incidents as divisible among different legal persons, and that these ingredients can be extended or constrained for the purpose of social control. The potential political implications of this theory has promoted hostility toward Honoré $(1961,110)$ from neoliberals, not least of which in response to his notion that the same thing might not be regarded as capable of being owned in different legal systems. Honoré argues that there is nothing strange about the notion of things "outside commerce," and he talks about the necessity of social control. As Honoré $(1961,110)$ puts it, "[t]he notion of things 'outside commerce,' not subject to private ownership but to special regulation by the state or public authorities, is an ancient one and has retained its importance in modern continental law."

This does not mean that Honoré's concept of ownership should be taken as the definitive statement (Hodgson 2013; Penner 1996, 1997). HRS represents a system of ownership that is more complex than the one conceived by Honoré. The accompanying facets of social and economic development necessitate further restructuring of Honoré's "bundle of rights" theory. Nevertheless, this theory may still be applicable by viewing HRS as one type of "split ownership" in which the standard incidents are divided among the state, the collective, and the peasants. It also represents a typical case of social control of ownership in the interests of related parties. Of course, this does not mean rejecting alternative bases for analyzing HRS, not least Karl Marx's idea of "individual property" (1961, 763; 1958).

In the section that follows, I use Honoré's account of the eleven ingredients of the full liberal concept of private ownership as a theoretical framework to examine how these ingredients are divided between the state, the collective, and the peasantry. I focus on the property rights that Chinese peasants hold under the current legal system. Then, I employ Honoré's account of the notion of title, split ownership, and social control to examine the issue of collective ownership in the village community, the administrative village, and the township. I conclude with the suggestion that the privatization of land is not the only way to pursue rural economic growth. The Chinese land system arrangement is a real alternative to neoliberal social, political, and economic policy. The general majority of the rural populace in China believes this system to be credible (Kung 2000; Kung and Liu 1997; Wang 1998). In this light, I argue that Honoré's concept of ownership is well worth considering.

\section{Chinese Peasants' Property Rights under the HRS}

Here, I use Honoré's analysis of full standard incidents of "full" individual ownership that can be divided between two or three persons as a theoretical framework to analyze how these incidents are distributed between three legal persons: the Chinese peasant, the collective, and the state. The analysis that follows shows how these eleven ingredients are divided between the state, the collective, and the peasants.

\section{"The Right to Possess"}

Honoré defines "the right to possess" as the right "to have exclusive physical control of a thing, or to have such control as the nature of the thing admits." He accords this right a major place in the concept of ownership by affirming it as "the foundation on which the whole superstructure of ownership rests" (Honoré 1961, 114). This right "may be divided into two aspects, the right (claim) to be put in exclusive control of a thing and the right to remain in control, viz. the claim that others should not, without permission, interfere" $(1961,114)$. 
The right to possess rural land is designated to the collective under the Chinese legal system, which provides a series of rules and procedures for obtaining this right. Neither the state, nor Chinese peasants are entitled to negate this right. The 1982 Constitution of the People's Republic of China provides the legal basis for the land ownership system. Articles 9 and 10 divide the land into rural land, suburban land, and city and urban land. Rural and suburban land belongs to the collective, while the city and urban land belongs to the state. Natural resources, such as forests, lakes, rivers, grassland, and wasteland, all belong to the state. These constitutional articles remained unchanged during the four revisions of the Constitution in 1988, 1993, 1999, and 2004. The right to possess rural land by the collectives is enshrined in the Constitution. Therefore, under the Constitution, neither the state, nor individual Chinese peasants have the right of possession over the plots of land that Chinese peasants use in rural areas. Only the collectives have that right.

Subsequent laws have reflected the above stipulations on the collective right to possess rural land in China. The first Land Administrative Law of 1986, for example, followed this principle. This is a recurring theme in subsequent Chinese laws. The 1999 Revised Land Administrative Law concentrated and consolidated the right of ownership in the hands of the central state and the collectives. A relevant extract from Article 8 of this law reads: "Land in rural and suburban areas is owned by peasant collectives, except for those portions of land which belong to the State as provided for by law; house sites and private plots of cropland and hilly land are owned by peasant collectives." Article 2 of the 2002 Law of the People's Republic of China on Land Contract in Rural Areas further stipulated that, "[f]or purposes of this Law, land in rural areas includes the arable land, forestlands and grasslands owned collectively by the peasants and by the State and used collectively by the peasants according to law, as well as other lands used for agriculture according to law." Here, the interpretation of "land in rural areas" is broad. Rural land refers to "arable land" that corresponds to rural land in the Constitution. In the 2007 Property Law of the People's Republic of China, the principle of land ownership of the state and the collective was restated. Clearly, the collective has a secure right to possess land, according to Chinese law and under the current legal system. In that sense, the right of possession - that is, "the foundation on which whole superstructure of ownership rests" - is an entitlement of the collective.

\section{The Right to Use}

Honoré $(1961,117)$ is well aware of two kinds of interpretation of the term "use": a wide interpretation that includes "management and income," and a narrow interpretation that refers to "the owner's personal use and enjoyment of the thing owned." In China, both interpretations are used. Moreover, there is a third interpretation which has an even wider meaning than Honoré's definition of "use" that has to do with "management and income." Following the introduction of HRS in China, the separation of "ownership" from "use" has been discussed in the context of the statement that the ownership of land belongs to the collective, but the right of use belongs to the peasants. This is known as the "two-tier" land system (Dong 1996; Zhang and Donaldson 2013).

The right to use is accorded to the peasants by the current legal system in China. A relevant extract from Article 10 of the Constitution (1982) reads: "All organizations and individuals who use land must make rational use of the land." Article 9 of the 1999 Revised Land Administrative Law of the People's Republic of China stipulates: "State-owned land and land owned by peasant collectives may be lawfully determined to be used by units or individuals." 
Honoré $(1961,117)$ recognizes this right as a "cardinal feature of ownership." In the context of the Chinese rural areas, it is this stipulation of use right that constitutes the difference between HRS and the former collective-the Commune System under Mao's regime. The introduction of HRS promoted agricultural growth during the period from 1979 to 1984 (Lin 1989, 1992; Wen 1989; McMillan, Whalley and Zhu 1989). As Hodgson (2013, 224) put it, "since the early 1980s, there has been a major distribution of usus and usus fructus rights from collectives to peasant farmers, leading to huge increases in agricultural productivity and launching China's 30-year growth explosion." The number of poor people in China has decreased from 250 million to 26.1 million today, accounting for a 70-percent reduction in the global number of people afflicted by poverty (Peng 2011). Peasants have obtained much autonomy in their production choices, such as adjustments in crop patterns in response to soil quality, temperature, rainfall, and other region-specific characteristics, thus gaining regional comparative advantages (Lardy 1983).

However, the establishment of peasants' rights to use land has been a long process. Before 1978, the right to farm land by individual families was forbidden by the central government. The Household Responsibility System was introduced gradually following 1979, after the Chinese Community Party's conference of December 1978, and completed in 1984. At first, "the right to use" given by the state refered to the household's "personal use and enjoyment of the thing owned," according to Honoré's narrow interpretation of "use." Gradually, this "right to use" was extended.

Chinese peasants are forbidden from selling their land use rights to others. The Constitution has remained unchanged in subsequent revised versions. A relevant extract from the 2004 Constitution of the People's Republic of China reads: "[N]o organization or individual may appropriate, buy, sell or otherwise engage in the transfer of land by unlawful means." The limitation is that land already allocated should be used solely for agricultural production.

Thus, Chinese peasants have the right to use the land allotted by the collective, but they do not have the right to sell or buy land. "Chinese farmers do have benefit-of-use rights (usus fructus), but these rights are currently not saleable or transferable" (Hodgson and Huang 2013, 611). As it is legally impossible to privatize collective ownership, arguments are mainly in the sphere of "use" rights. For example, some international organizations, such as the OECD (2011) and some media, call for "hidden" privatization of land use rights (Righter 2008; Stanway 2008; Wong 2008).

However, as some scholars like Qian Forrest Zhang and John Donaldson $(2013,255)$ have pointed out, the current legal institutional arrangement on use rights is positive in that it promotes economic growth and avoids the negative aspects of land privatization. There would be harmful results if land use rights could be sold. As Zhang and Donaldson (2013, 256-257) rightly pointed out, it "would likely return China to days of concentrated land ownership and large numbers of landless farmers. Exploitation by landlords, large capitalist farmers, and political leaders would once again dominate class relations in rural China."

As early as the 1990s, analysts like Prosterman and Hanstad (1990) asserted that the best way to pursue economic growth in agriculture was to establish a program of land privatization via land titling or registration in order to solve a host of problems brought about by HRS. However, as Xiaoxuan Dong 1996 noted, the positive aspect of land privatization in the Chinese context has been exaggerated and related problems can be solved without a program of land privatization. The current land system, which does not allow the land or land use rights to be sold, is one kind of protection for peasants against wealthier and more politically powerful groups. I will return to this topic later when I analyze the right to capital.

\section{The Right to Manage}


The right to manage, for Honore, is the right to "decide how and by whom the thing owned shall be used." It embodies a set of powers by the "owner" (Honoré 1961, 117). In Honoré's view, "making contracts relating to the thing owned" is one popular form of management (1961, 117). Although a contract is very important, it should not be exaggerated "because many powers of management are exercised otherwise than by way of contract, not to mention powers of alienation" (Honoré 1961, 118).

Chinese peasants have the power of contracting out the land allotted to them under the current legal system. It takes the form of peasants' subcontracting land rather than farming it themselves. Originally, the Household Responsibility System was designed to secure families an income. In 1984, individual households were allowed to transfer their contracted land to another household on condition that the local cooperative approves. This was permitted so that, if a household could not utilize its parcel of land because of sickness, death, or other problems, there was an alternative to not using the land. In 1987, the right to rent land to another household was further liberalized by the Thirteenth Party Congress (Hsu 1990). This was criticized as a case of incipient capitalism. As some scholars rightly noted, "such occurrences were rare. In any event, land remained public and chances for renewed capitalism seemed small" (Hsu 1990, 845). The revision of the Constitution in 1988 legitimized land rent and confirmed the principle of transfer under a "valued use system" by adding that "the right to the use of land may be transferred according to law."

As Chinese peasants have contracts with the collective, the right to management is, in essence, a sublet. Since subletting was permitted by the 1988 Revised Constitution, peasants can also make contracts relating to the land and rent their own land to others. Article 128 of the 2007 Property Law of the People's Republic of China also permits the subcontracting of land.

This fact, as well as the growing relative importance of management compared with personal use, should not be exaggerated in the current socio-economic situation. As I later explain, the power of alienation is in the hands of the state, although the power of subletting is also limited by the Rural Contracting Law of March 2003. According to this law, the transfer must meet the following requirements: it must be "a voluntary, consultative and paid lease"; the land must still be used for agricultural purposes; the land ownership must still belong to the collective; the term of lease must not exceed thirty years; and the new lessee should have agricultural management capacity. In obtaining lease rights, members of the same village have priority.

Although contracting contributes to land concentration, subletting has not yet become a completely market-oriented tenant system (Zhu Ling and Jiang 1993). This is because rural land is still an instrument for the majority of peasants to meet their basic needs rather than to make a profit, and because the legislation allows a rental market rather than a selling market. For example, a rule of the Administrative Law of 1999 stipulates that "construction land, in fact all rural land - be it agricultural or non-agricultural land - cannot be mortgaged." This rule cannot be changed in a short time, industrialization and urbanization likely being a long process. Legislation provides protection for some vulnerable groups, such as elderly people in rural area, in that they have at least one share of land as "minimal property" to meet their basic subsistence needs.

\section{The Right to the Income}

Honoré considers "to use or occupy a thing" as "the simplest way of deriving an income from it, of enjoying it," and he takes as an example "the rent-free use or occupation of a house considered by English income tax legislation to be a form of income" (Honoré 1961, 118). He 
also notes that there are many forms of income, such as fruits, rents, and profits. The benefits might come from personal use of a thing or allowing others to use it for reward

Prior to the instituting of HRS, under the communal system, the basic production and accounting unit was the production team. Distribution was not directly linked to work performance. The issue of "free-riding" was unavoidable (Lin 1987, 1988, 1989). In December 1978, farmers from eighteen households in Xiaogang village in Anhui Province secretly adopted a system, whereby each household would take responsibility for its own parcel of land and take ownership of its output (Fewsmith 1994; Zhou 1996). This meant that peasants not only had the income, but also kept the produce once they had met their basic obligations to the state (Qi 1999, 20). After the state procurement and meeting their need for food, they could also sell the harvest, thus also enjoying the profit from their personal use of the land. The right to the income had been transferred from the collective to the individual producers. This secret "revolution" was the springboard for a slow change in government policy, and ultimately led to the explosion in Chinese rural economic growth and the so-called Chinese economic miracle. This type of income comes from the personal use of land. When Chinese peasants were given the right to sublet, they also acquired the ability to enjoy the "rents from allowing others to use it for profit." Therefore, since the introduction of HRS, Chinese peasants have enjoyed the right to an income (fruits, rents, profits) from their land either by working it themselves or by subletting to others on the condition that they meet "(1) quota deliveries; (2) agricultural tax; and (3) village community charges" (Zhu and Jiang 1993, 458).

Since 2004, agricultural taxes and other types of rural fees have been eliminated. Therefore, the simple occupation of land is a form of income. "These policies greatly benefited rural families" (Andreas, 2012, 134). Those who already had stable sources of off-farm income and work opportunities could sublet their land to those who wished to expand their farms. Thus the lessors have the rent and lessees have the profit after deducting the rent (Zhu and Jiang 1993). By subletting their land, Chinese peasants could charge rent and form "a minimum property," thereby avoiding complete poverty and destitution in case of a temporary or long-term job loss or other calamity (Zhang and Donaldson 2013, 270).

The 2007 Property Law of the People's Republic of China provides the right to income from the land. Article 125 of the law uses the term "benefit" to describe the right to income. The article reads: "Contractors for the right to land management shall, in accordance with law, have the right to possess, use, and benefit from the cultivated land, forestlands, grasslands, etc. which are under their contractual management."

In summary, Chinese peasants are entitled to the right to income under the current Household Responsibility System. Undoubtedly, huge regional inequalities still exist and a large urban/rural gap remains (Sicular et al. 2007). However, this relatively equal distribution of land according to family size mitigates these inequalities (Zhu 1991), as use rights benefit peasants.

\section{The Right to the Capital}

For Honore $(1961,119)$, the right to the capital comprises two aspects: "the power to alienate the thing" and "the liberty to consume, waste, or destroy the whole or part of it." This right "has an important economic aspect." The former aspect of it, however, is more important because "most people do not willfully destroy permanent assets" (Honoré 1961, 119).

Under HRS, both Chinese peasants and the collectives have no power to alienate the land.Peter Nolan well notes the reason why the CCP does not allow peasants sell their land. 
In agriculture, the 'de-collectivisation' of farmland was not followed by the establishment private property rights in land. The CCP did not wish to allow the emergence of a landlord class, and, therefore, land cannot be bought and sold. Rather, the village community remained the owner of farmland, controlling the terms on which it was operated by peasant households, endeavouring to ensure that farm households had equal access to farmland. (Nolan, 1993, 74)

Neither the peasants, nor the collectives have the right to sell, mortgage, or in any way alienate all or part of the land. Article 10 of the Revised 2004 Constitution of the People's Republic of China contains a relevant provision: "No organization or individual may appropriate, buy, sell or otherwise engage in the transfer of land by unlawful means. The right to the use of land may be transferred according to law." Both the collectives and the peasantry are expected to use land rationally. It is clear that they do not have "the liberty to consume, waste, or destroy the whole or part of it." They are obliged to use it rationally and have no right to the capital. As Hodgson and Huang $(2013,611)$ note, "in China, rights of sale and transferability are unambiguously in the hands of local or national state institutions." The state alone retains the alienation rights. According to the NPC Legal Affairs Work Committee, "the right to profit of state-owned land belongs to the central people's government and that the State Council may decide the distribution of profits from state-owned land" (RFGW 1998, 37). As Ho $(2001,404)$ observes, the state's right to profit is merely a principle. In practice, however, the state "can entrust local people's governments and state-owned companies to exercise this right."

However, even if the state wants to sell the collective land, it has to follow certain procedures. As Zhu and Jiang $(1993,447)$ observe, "[t]he state cannot directly dispose of village farmland because it is in collective ownership. In order to construct roads, railway and state-owned enterprises, the state has to compensate village communities for taking over the plots of their land." The rules of Article 10 of the Revised 2004 Constitution reads: "The State may, in the public interest and in accordance with the provisions of law, expropriate or requisition land for its use and shall make compensation for the land expropriated or requisitioned." In this sense, the state cannot directly sell the collective land.

This provision of the Chinese legal system is definitely "inconsistent with the liberal idea of ownership" (Honoré 1961, 119). Some writers think that only the right to sell can be counted as a property right, and that without it, there would be no rights at all. As Ostrom $(2010,650)$ notes, "many scholars presumed that unless users possessed alienation rights - the right to sell their property - they did not have any property rights" (Alchian and Demsetz 1973; Anderson and Hill 1990; Posner 1975). For others like those belonging to the law and economic movement, the right to a thing must be transferable. As Denise R. Johnson (2007) observes:

On the other end of the spectrum, the law and economics movement treats property exclusively from a market perspective. The market perspective treats all resources that have market value, defined as exchange value, as property. From this perspective, the social value question is why the law prohibits markets in certain goods and not others. For example, why do we prohibit the sale of babies or human organs, but not the sale of other things that have exchange value? To the law and economics people, the critical issue in any system of property rights is that rights must be freely transferable. (Johnson 2007, 257)

In this sense, for Honoré $(1961,147)$, "the sphere of operation of ownership in the liberal sense is narrowed." Compared with the neoliberals, Honoré has a wide view of property rights. 
As he says, "[i]ndeed, in nearly all systems there will be some things to which not all the standard incidents apply, some things which cannot be sold or left by will” (Honoré 1961, 110). Honoré $(1961,147)$ notes that, in the former Soviet Union, for example, rural collective land, natural resources, and business were withdrawn from "personal property." In his view, "the notion of things 'outside commerce,' not subject to private ownership but to special regulation by the state or public authorities, is an ancient one and has retained its importance in modern continental law" (Honoré 1961, 110). Thus, Honoré provides a very good balance of countering the liberal concept of ownership by defining as private property everything that can be exchanged in the socalled "natural" market.

\section{The Right to Security}

Honoré $(1961,120)$ defines the right to security as "an important aspect of the owner's position ... that he should be able to look forward to remaining owner indefinitely if he so chooses and he remains solvent. "Legally, this is an immunity from expropriation, based on rules which provide that, apart from bankruptcy and execution for debt, the transmission of ownership is consensual" (Honoré, 1961, 120)." Under the lease period, Chinese peasants do have the right to security. The land allocated can be neither sold nor mortgaged. They do not worry that their land will be expropriated for bankruptcy or an execution of debt. This security is different from the liberal sense of security in that land can be sold or mortgaged. Thus, the Chinese right to security in land are greater than those in other developing countries (Doshi et al. 2011; Zhang and Donaldson 2013).

The important insight in Honore thought is that he does not regard the state or public's expropriation as in absolute conflict with the owner's interest. As he argues: "a general right to security, availing against others, is consistent with the existence of a power to expropriate or divest in the state or public authorities" $(1961,120)$. In contrast to the view that "ownership" is "absolute," a view which is used to "emphasize its exemption from social control," he says:

In the last sense, ownership has never been absolute. Even in the most individualistic ages of Rome and the United States, it has had a social aspect. This has usually been expressed in such incidents of ownership as the prohibition of harmful use, liability to execution for debt, to taxation, and to expropriation by the public authority. (Honoré, $1961,145-146)$

Naturally, the compensation for this expropriation should be adequate and fair. As Honore $(1961,120)$ states, "it is important that when expropriation takes place, adequate compensation should be paid; but a general power to expropriate subject to paying compensation would be fatal to the institution of ownership as we know it." Honoré realizes that emphazing the social aspect of ownership is different from period to period $(1961,146)$. In addition, socialism has also altered the relationship between government and ownership in regard to some important types of property, such as land and business (Honoré 1961, 146). Chinese legal-system rules stipulate that compensation should be paid to peasants, as demonstrated in the above extract from the Revised 2004 Constitution. Some scholars nevertheless claim that Chinese peasants have not obtained adequate or fair compensation from the state or local governments (Hodgson and Huang 2013, 15).

The difficulty is that, since compensation is distributed between the collectives and the peasants, whether the peasants should get the full market price for their expropriated land is an issue for debate. Chinese leaders have also been aware of this issue. For instance, on 28 December 
2011, the then Chinese Premier Wen, in a statement at a national conference on rural affairs, called on local officials to better protect the rights of farmers and ensure that they received a bigger share of profits from the conversion of land to industrial and residential use (Zheng 2011). To adequately protect the interests of both parties is very complicated but Chinese peasants should be given a fair share of the profit from selling land and subsequent economic growth. However, privatization of land cannot solve this issue (Zhang and Donaldson 2013).

\section{The Incident of Transmissibility}

'Duration' is identified by Honoré 'one of the main characteristics of the owner's interest' $(1961,121)$. Honoré takes "unlimited duration" as the starting point. For him, it consists of two elements: "transmissibility" and "absence of term". Let us first consider the former.

The incident of transmissibility is that "the interest can be transmitted to the holder's successors and so on ad infinitum" (Honoré 1961, 121). As this incident depends on inheritance, it can be used interchangeably with "heritability" (Honoré 1961, 121) or "inheritability". The transmissibility is clearly something in which "the holder has an economic interest" and is "of value to him" (Honoré 1961, 122).

Chinese peasants cannot bequeath their rights to their heirs through the generations like in western societies. However, during the period of contract, their rights of use, management, and income can be inherited by their successors. For example, as Zhu and Jiang $(1993,446)$ observe, the duration of Chinese peasants' use rights were stipulated to be fifteen years by the central government in 1984. During these fifteen years, the use rights "could be inherited by a farmer's descendants and be transferred to others with the approval of the village committee." As there are no agricultural fees and taxes (since 2004), the longer the lease period, the greater the Chinese peasants' stake in the land. With the gradual increase of the lease to thirties years in 1993, Chinese peasants became entitled to more rights to their land. Thus, they partially hold the incident of transmissibility, and the "transmissibility" is limited. The collectives can pass their transmissibility to the next generation.

\section{The Incident of Absence of Term}

The second part of what is called "duration" is the absence of a term. Honoré $(1961,122)$ distinguishes three types of interests: determinate, indeterminate, and determinable interests. The first type of interests is that those interests that are to be determined at a future date, sure to determine at a future date, or on the occurrence of a future event. Leases, copyrights, etc. fall into this category.

The rules of China's present legal system provide "determinate interests" for the peasants. For example, the Land Administration Law of 1999 provides a thirty-year lease period. The Rural Contract Law of 2003 also stipulates that the rural land lease is thirties years. The Property Law of the People's Republic of China of 2007 restates that "the duration of such contracts is thirty years," but extends other terms of duration.

It is necessary to note that this incident of determinate interests can be stretched or shortened. The gradual increase of the duration of contracts within the HRS confirms Honoré's insights. The crucial issue is "how far private ownership should stretch and to what extent it should be modified in the public interest" (Honoré 1961, 109). Initially, the government allowed a lease period of only five years, extending it to fifteen in 1984 and to thirty in 1993 (Cheng and Tang 1996, 44). 
The second group of interests is "indeterminate interests," "such as ownership and casements, to which no term is set” (Honoré 1961, 122). Honoré notes that the concept of "indeterminate interests" depends on the notion of transmissibility because human beings are mortal. He further states that "indeterminate interests are really determinable" as "the rules of legal systems always provide some contingencies such as bankruptcy, sale in execution, or state expropriation on which the holder of an interest may lose it" (Honoré 1961, 123). Since the collective as a whole can survive from generation to generation, the collective would be able to continue in the enjoyment of ownership in perpetuity. Therefore, the collective interests of ownership are provided by the Chinese legal system as indeterminate. On the other hand, with state expropriation, the collective may lose an interest in the land. Therefore, the collective interests are actually determinable. This is Honoré's third group of interests - "determinable interests" - "to which no term is set" (Honoré 1961, 123).

It is widely assumed that the longer the length of lease, the more secure Chinese peasants feel. For example, Zhu and Jiang write (1993, 456): "Owing to the frequency of land redistribution, farmers do not possess secure tenure and the term of their tenure is too short. They are uncertain about how land will be allotted in the future. This has resulted in them pursuing short-term profits from land to the neglect of long-term investment." This is also the reason that some scholars and organizations call for a seventy-year land tenure (Hodgson and Huang 2013, 616-617; OECD 2011, 17; Palomar 2002) or a "permanent" lease period for Chinese peasants (Wang 1989; Zhou 1991).

However, this must not necessarily be the case. Indeed, land tenure is not secure when there are too frequent changes to the rules governing leasing and subleasing. However, in the end, the Chinese central government has shown greater confidence in its establishment of the Household Responsibility System which extended the lease period from five to thirty years. J.K. Kung and Shouying Liu (1997) show that it is not true that the longer the lease, the more secure peasants feel, as in the private property system. Indeed, "villagers prefer short-term contracts" (Kung and Liu 1997, 51) and they "do not want stable tenure for as long as 30 years" (Kung and Liu 1997, 60). "Farmers largely prefer to re-adjust land on the margins from time to time resolve the problem of household demographic change" (Kung and Liu 1997, 60). This is quite contradictory to the Western mainstream economists' assumption that the longer of the tenure the securer of the tenure.

\section{The Prohibition of Harmful Use}

This incident is defined by Honoré $(1961,124)$ as an “owner's liberty to use and manage the thing owned as he chooses ... subject to the condition that uses harmful to other members of society are forbidden." This is not "often thought of as incidents of ownership" (1961, 124). Similar to "the expropriability and executability of a thing," it "is not an incident of value to the owner, but a restriction on the owner's rights imposed in the social interest" (Honore 1961, 123). Although what is counted as harm is disputed, it is "essential to the existence of an orderly community” (Honoré 1961, 124). In Honoré's view (1961, 124), it is very important that, "without them, 'ownership' would be a destructive force." Along with other incidents, such as the "liability to execution for debt, to taxation, and to expropriation by the public authority," "ownership has never been absolute" and "has had a social aspect [to it]" (Honoré 1961, 146).

Chinese law requires that rural land be used "rationally." Article 10 of the Revised 2004 Constitution stipulates that "[a]ll organizations and individuals using land must ensure its rational use." Other statutes reinforce this limitation on land use. Article 9 of the1999 Revised Land Administrative Law of the People's Republic of China reads: "Units and individuals that 
use land shall have the obligation to protect and manage the land and make rational use of it." For example, Chinese peasants can grow any grain, fruits, and vegetables, but they cannot grow poppies for opium. The collective has no right to use arable land for residential purposes either, such as for building a home (Park and Lee 2012).

China has rigorous land use regulation and a very strict arable land protection system. This is a crucial factor influencing rural land property rights because land is an extremely scarce resource, thus protecting farmland from misuse to assure food security has always been a Chinese government's priority. The government takes self-sufficiency in food production most seriously, especially in light of some reports (State Land Administration Bureau, 1 June 1987) and main official media (People's Daily, 28 January 1988) about the loss of farmland and the decline in soil fertility. With the development of industrialization and urbanization in China, rural land has inevitably been converted to urban construction land (Ash and Edmonds 1998; Lin 2009; Lin and Ho 2003; Wang et al. 2012). Lester Brown (1995) shocked the Chinese government by his prediction that China would face food shortages due to the substantial loss of arable land (see also Ash and Edmonds 1998; Smile 1999). No matter whether Brown exaggerated the situation, food security was and still is one of China's top priorities as the country has to feed about 22 percent of the world's population with just 7.0-8.0 percent of the globe's agricultural land (Jiang 2014).

\section{Liability to Execution}

The incident of liability to execution may be called "executability," defined by Honoré $(1961,123)$ as "the liability of the owner's interest to be taken away from him for debt, either by execution of a judgment debt or on insolvency." It is also a kind of social control similar to the prohibition of harmful use and other incidents (Honoré, 1961, 125). Honoré $(1961,124)$ realizes the importance of this incident in his "growth of credit" concept. As he writes:

Without such a general liability the growth of credit would be impeded and ownership would, again, be an instrument by which the owner could defraud his creditors. This incident, therefore, which may be called executability, seems to constitute one of the standard ingredients of the liberal idea of ownership. (Honoré, 1961, 124)

Indeed, this incident is one of the standard ingredients of the liberal idea of ownership. It adjusts the relationship between an owner and his creditor. Without this incident, it is impossible for the growth of credit. Later writers have further emphasized the importance of this incident in the development of capitalism (Arner et al. 2007; Arrunãda 2012; de Soto 2000; Hodgson 2013; Steiger 2008). Hernando de Soto (2000), for example, has been hugely influential in shaping South America's discussions, closely affiliated to the Chicago neoliberal school. He is arguing in terms of inclusiveness that small-property title is a condition of participation. As de Soto states:

The existence of such massive exclusion generates two parallel economies, legal and extra-legal. An elite minority enjoys the economic benefits of the law and globalization, while the majority of entrepreneurs are stuck in poverty, operating in the shadows of the law. (Hernando de Soto)

He also writes: "By our calculations, the total value of the real estate held but not legally owned by the poor of the Third World and former communist nations is at least \$9.3 trillion (de Soto, 2000, 
35)." In other words, the poor's assets which add up to more than $\$ 10$ trillion worldwide are dead capital 'in the shadows of the law'. One of feature of the dead "dead capital in the shadows of the law" is that it "cannot be used as collateral for a loan (de Soto, 2000, 35)."

Hernando de Soto is by no means alone in insisting that land should serve as collateral. Gershon Feder and Tongroj Onchan (1989), for example, have previously developed the argument that the provision of land as security for loans reduces the cost of borrowing and increases the supply of credit to farmers. Gershon Feder et al. (1989) argue that the lack of collateral assets limits Chinese peasants' access to institutional credit, especially to mediumand long-term loans. Therefore, granting peasants the right to pledge contracted land for loans, and protecting the lender's right to foreclose on mortgaged land in case of default, were seen as an essential step toward the development of a credit market in rural China (Johnson 1993; Lin 1989b). During the 2008 Third Plenary Session of the Seventeenth Communist Party Central Committee, many notable scholars echoed this thinking, speculating on the possible privatization of land. For example, Zhu Keliang noted that, "[i]f all the speculations are true, if senior leadership is going to lift all the restrictions out the door, I'd say this is a great positive. It'll free up the dead capital and allow all this wealth to materialize" (in Wong 2008, online). Scott Rozelle, a leading expert on China's agriculture, enthused that "[t]his is potentially the real deal ... [If enacted] it gives a household a very valuable asset that it can collateralize or sell” (in Magnier 2008, online).

In China's legal system, this incident is withdrawn from the collectives and the peasants, and placed under the control of the state. As mentioned earlier, under the current legal system, the peasants have no absolute right to sell or mortgage the land, only to rent (or sublet) it. The Revised Administrative Law of 1999 stipulates that "construction land, in fact all rural land - be it agricultural or non-agricultural land - cannot be mortgaged." The purpose of this regulation is to eliminate this crucial institutional mechanism for the development of capitalism. This kind of legal construction of ownership is inconsistent with the liberal idea of ownership, and gives neoliberals the ammunition to criticize China's HRS. Neoliberal property rights theorists would argue that the lack of executability handicaps China's farmers in terms of their ability to borrow to finance land improvements, machinery, and so on. According to this belief, some scholars both within and outside China - have called for the right of Chinese peasants to sell or mortgage land in order to protect their rights, so that they can benefit from their use rights (Fewsmith 2008; Sargeson 2012; Qin 2007).

Although Hodgson and Huang $(2013,614)$ observe that "collateralization also depends crucially on viable and accessible banking, land registration, and legal institutions," they conclude that "China's current land institutions cultivate corruption rather than the productive collateralization of rural assets. These anachronistic institutions are brakes on development."

They further develop this idea to state:

If a rural family wishes to move elsewhere and abandons the land, then they would be required to sell the lease to the village committee or another buyer. General leasehold salability could lead to some concentration of land ownership and the development of agricultural corporations or cooperatives. Along with the ability to mortgage land, some concentration of leasehold tenure will facilitate investment in agricultural technology and lead to economies of scale. (Hodgson and Huang 2013, 17)

Although this sounds good in promoting the interest of those who want to leave rural areas, questions arise: What, after selling the lease to the village committee or another buyer, will 
happen if people want to return? What will happen to those unable to pay after the foreclosure of their land for debts? Zhu and Jiang (1993) observe that most peasants in China were still pursuing subsistence production rather than commercial production in the early 1990s. ${ }^{2}$ The land is not only a means of production, but a basic form of social security (Guo 2003; Dong 1996; Zhang, Rozelle and Huang 2001). It is the "minimal property" in the means of production as compared with "minimal welfare" in other spheres, as the case is in developed western countries. The neoliberal thinkers ignore the negative aspect of private property or consider it a necessary price for economic growth, no matter the cost to the peasantry. The negative consequences of "the foreclosure of a peasant's mortgaged land" would be "involuntary unemployment and rural destitution" (Dong 1996, 921). Furthermore, such a resulting state of affairs "would only exacerbate class inequality and social tensions in rural China, and further weaken farmers' positions in dealing with more powerful actors" (Zhang and Donaldson 2013, 255).

At the same time, the benefits of allowing land as collateral have been exaggerated. For example, although 85.8 percent of farmers in Asia and 60.30 percent in Latin America were private owners (Ostuka, Chuma and Hayami 1992), as many as 85 percent of the farmers on these two continents had no access to formal credit (Braverman and Guasch 1986), not because of the lack of "secure" property rights in land, but as a direct result from the cost for financial institutions to deal with small producers. As Chinese farms are homogenously small, private property rights in land have no big effect on relaxing the credit constraints on Chinese agriculture (Dong 1996, 921). The fact that the land allocated to Chinese peasants under HRS cannot be sold or mortgaged is actually a protection for Chinese peasants, compared to peasants in other countries (Doshi et al. 2011; Krishna 2004).

Undeniably, obtaining credit is a chronic problem in China's agricultural sector. Solving this problem does not mean that the land must be collateralized. For example, the existing village credit cooperative would be one way to solve this problem. By the end of 1991, about 16 percent of Chinese villages had established cooperative fund associations (TFRCE 1993, 90-91). These village cooperatives can use the collective property as security. For example, according to the Rural Sample Survey Office's survey of rural private enterprises from eleven Chinese provinces conducted in 1987, 40.8 percent of these enterprises financed their initial investment with institutional loans, and 30.4 percent of these loans were guaranteed by village cooperatives using the collective property as security (RSSO 1992, 363). As some researchers have pointed out, the cooperative has a series of advantages in supplying small family farms with larger credit lines at lower interest rates. It can monitor the borrower's behavior closely, influence their actions directly, and discipline borrowers for improper behavior (Dong 1996, 922). It can also act as a third-party guarantee for peasant households in the direct borrowing of institutional loans (Bardhan 1980; Binswanger and Rosenzweig 1986; Braverman and Guasch 1991). Furthermore, as Zhang and Donaldson $(2013,255)$ note, the microfinance by the government is another effective way to make peasants access emergency loans (Donaldson 2009).

\section{"Residuary" Character}

For Honoré (1961, 126), since a legal system recognizes "interests in things less than ownership," there is an incident of "residuary character" of ownership. In other words, the issue of residuary character of an ownership is that that "an owner has a residuary right in the things owned (Honoré, 1961, 127)." It comes from the fact that a legal system recognizes both ownership and lesser interests. Honoré $(1961,127)$ suggests that the "owner" is the ultimate 
residuary, providing a detailed analysis of how the "corresponding rights" are vested in the case of sublease.

First, let me use Honoré statement to analyze the lease and sublease cases. Under the current legal system, the collective (A) is the owner of rural arable land and the peasant (B) holds the lease that, under the Revised Land Administration Law of 1999, is for thirty years. A Chinese peasant (B)'s interest in his/her small plot of land is an interest less than an ownership interest. When it terminates, the corresponding rights are vested in the hands of the collective. When this lease period terminates, the "owner" (A) can exercise the corresponding rights. For example, the collective can redistribute the land to the previous tenant or to other members in the village. (B) can sublet the small plot of land to a third party (C). Thus, (B) leases the land from village "A" and then he/she can sublease the land to (C) (or another party). On the determination of a sublease, after the extinction of (C)'s rights, the latter become exercisable by (B), not by the "owner" (A) of the property. If the collective land were expropriated by the state, then the state obtains ownership. The state's interest becomes a real ownership rather than "a mere expectancy (Honoré, 1961, 128)." Therefore, we can safely say that the state's interest can be both a real and an expectant ownership. In the section that follows, I analyze collective land ownership in three aspects.

\section{Collective Land Ownership}

\section{The Distribution and Redistribution of Land by the Collective}

The collective can appropriate and redistribute lease land whenever it deems it necessary. However, this power should not be overestimated. The redistribution of land by the collective may sometimes be necessary, such as in response to demographic changes (Kung and Liu 1997). Ho $(2013,1108)$ provides one example: "Suppose somebody in a household dies, while a newborn can be welcomed in another; the collective faces substantial social pressure to redistribute land among these two households." Thus, "the redistributions are a sheer necessity to ensure that everyone in the village has equal access to land". In this sense, everyone can be guaranteed access to land based on this redistribution. Chinese peasants generally feel this system to be truly fair and equal, with the agricultural lease system in this sense functioning as a social welfare net for them (Guhan1994). Redistribution is not frequent or large-scale, but rather functions as an adjustment mechanism (Kung 2000).

This kind of land readjustment is supported by the majority of farmers (Kung 1995, 2000; Kung and Liu 1997; Wang 1998). Furthermore, the power of the villagers' committee is limited by law. The democracy of the collective is also strengthened by democratic elections (Wang 1998) and the Revised Land Administration Law of 1999 reiterates the policy of 1997 that, in principle, guarantees an unchangeable land lease of thirty years and checks the power of villagers' committee by stipulating that leased land can be redistributed only with the approval of twothirds of the villagers' congress or delegates.

\section{The Three-Level Ownership}

One of the foundations of HRS is collective ownership. In the Chinese legal system, the collectives have the title to rural land. For example, a relevant extract from Article 10 of the Revised 2004 Constitution reads: "[L]and in the rural and suburban areas is owned by collectives except for those portions which belong to the state in accordance with the law." Between 1958 and 1979 , collectivization with a three-tier system of administration was developed. These tiers 
include: the people's commune, the production brigade, and the production team. Since the introduction of the Household Responsibility System from 1979 to 1984, these three levels have evolved into (i) the present township/town, (ii) the administrative village, and (iii) the natural village or villagers' group. These three levels of the collective are legally entitled to represent land ownership as laid down in the Revised Land Administration Law:

The land owned by the farmers' collective is by law owned by the farmers' collective of the village, and managed and administered by the village collective economic organization or the villagers' committee; what is already owned by more than two rural collective economic organizations of the farmers' collective is managed and administered by each of these rural collective economic organizations or the villagers' groups; what is already owned by the farmers' collective of the township (town) is managed and administered by the rural collective economic organization of the township (town).

The National People's Congress (NPC) NPC Legal Committee makes several important clarifications and three stipulations. First, "the land owned by the farmers' collective is by law owned by the farmers' collective of the village" means that this land is "owned by the farmers' collective of the administrative village." The collective is different from the villagers' committee in that the collective within an administrative village is the owner of the land, while the villagers' committee has the right to manage and lease it. Second, "if land prior to the reforms belonged to more than two production teams, their land is now still owned by each of these rural collective economic organizations or the villagers' groups equivalent to the former production teams." Third, "what is already owned by the farmers' collective of the township (town) means that "the land of the people's commune ... after its transformation into the township/town still belongs to the farmers' collective of the township/town."

According to the Revised Land Administration Law, the "farmers' collective" or the "collective economic organization" is entitled to land ownership, whereas the "collective economic organization of the township (town)," the "villagers' committee," and the "villagers' group" are entitled only to the right of management and administration of land. Thus, there is a difference between the institutions that manage and administer land and the collectives that hold ownership.

\section{The Title of Ownership}

In analyzing "one or many titles," Honoré makes a distinction between "uni-titular" and "multi-titular" based on the number of independent titles to a property. He realizes that the weakness of "uni-titular" is in the fact that "it may seem to leave unprotected persons whose interests are deserving of protection” (Honoré 1961, 137).

The 1997 survey of the Central Policy Research Office found that the land was leased by these three levels to the following shares: the administrative village accounted for 60.5 percent, the villagers' group accounted for 32.3 percent, the township for 1.1 percent, and other categories for 3.0 percent. Chinese law provides protection for this multi-level system. The three different levels are granted a title to rural land. As the three-level ownership is a historical fact, all three levels need protection by law.

At present, there is a debate on how many titles should be guaranteed by law. Some argue that the township should be cancelled since the commune was dismantled and its economic 
function no longer exists. During the NPC debates on the Revised Land Administration Law, the Central Policy Research Office commented:

Now that the commune has been changed into the township/town, the brigade into the villagers' committee, and the team into the villagers' group, there is no longer any collective economic organization. To vest the collective ownership of land in the villagers' committee and the villagers' group is more attuned to some who championed granting ownership to the administrative as well as the natural village. (RFGW 1998, $338,395)$

The Central Policy Research Office also argued that the collective ownership should be vested in two levels: the villagers' committee and the villagers' group. Others have insisted that the village group should have no part in land ownership. For example, from the perspective of Zhejiang province, "[s]ome towns have already abolished the limits of the natural village (villagers' group) ... If we allow ownership to the villagers' group, town and village planning will be difficult to implement, which will hinder economic growth" (RFGW 1998, 366). Therefore, it was proposed that the "Land Administration Law changes the three-level ownership of collective land into a two-level ownership. In other words, the ownership right to collective land of the villagers' group is not stipulated, or the three-level ownership is uniformly administrated by the [administrative] village" (RFGW 1998, 366).

In my view, these three levels of ownership titles were formed over many years, and are still effective under the present circumstances and the title system is clear. In Ho's account of the land dispute between the Shiqiao State Reservoir and the Number Three Villagers' Group of X county, the intermediate people's court allowed the claim of the villagers' group and recognized the ownership of land by the lowest collective level (Ho 2001, 411-412).

The structure of the three-level collective is a historical and necessary process, as well as a political and legal construction. The township is the lowest tier of governmental organization and this allows the state to intervene and control the process. The villagers' group is basically a kinship group, the members of which have long lived and worked together. As a natural community, its members have a close relationship with each other. The administrative village is an intermediate level and serves as a channel between the state and civil society. It is an organization that has a relative "autonomy" in governing and managing its common-pool resource and represents the interests of its members.

\section{Conclusion}

Rural land ownership in contemporary China is complicated. We need a clear theoretical framework to understand and assess it. There are many types of theories about the "bundle of property rights." Demsetz's theory is useful for the neoliberal framework, which reflects his view of privatization as the only way to avoid the tragedy of common property and as the precondition of economic growth. The great strength of Honoré's position is that he recognizes different types of property rights, and the liberal conception of full private property rights represents only one such type, further being subject to variants and alternatives. Honoré classifies eleven "leading incidents" or types of rights that, in principle, can be in the hands of different legal persons. He also discusses how far private ownership should stretch and to what extent it should be modified in the public interest, equally respecting both those who have the greatest and the least interest in a thing. 
Honoré's concept provides a clear concept for understanding of the property rights that Chinese peasants have under the current HRS land system. For example, Chinese peasants have the right to use and manage land, the right to income and security, as well as the duty not to destroy the land. They also have a partial right of residual control in case of sublease, a determinate interest of absence of a term, and a partial right to pass on the lease or mortgage their land. Thus, they do not have to worry about having their land taken away for debt or lose it to a "distressed sell." The current legal system provides them with protection and long-term security. The right of possession is given to the collective for the public good. The right to capital belongs to the state, and it is in the public interest to be so. The Chinese legal system, therefore, provides a clear and secure property rights structure for the peasants, taking a historical and dialectic approach to the issue of ownership. Land privatization is not the way to protect peasants' rights and interests. To solve rural problems, China should continue with the current land ownership structure and reinforce HRS, rather than weaken it. The peasants' preference must be considered and respected in any policy-making.

\section{Footnotes}

${ }^{1}$ It was probably coined by William Forster Lloyd and later used by Garrett Hardin. As David Harvey $(2012,68)$ observes, it has been used to justify the privatization of land.

${ }^{2}$ This is still true today, just as they wrote twenty-two years ago.

\section{References}

Alchian, A. Armen and Harold Demsetz. "The Property Rights Paradigm." Journal of Economic History 33, 1(1973):16-27.

Alexander, G.S. Commodity and Propriety: Competing Visions of Property in American Legal Thought, 1776-1970. Chicago, IL: Chicago University Press, 1997.

Anderson, Terry L., and Peter J. Hill. "The Race for Property Rights.” Journal of Law and Economics 33, 1 (1990.): 177-197.

Andreas, Joel. "Sino-Seismology." New Left Review 76 (July-August 2012): 128-135.

Arner, Douglas W., Charles.D. Booth, Paul Lejot and Berry F.C. Hsu. "Property Rights, Collateral, Creditor Rights, and Insolvency in East Asia.” Texas International Law Journal 42 (2007): 515-559.

Arrunãda, Benito. Institutional Foundations of Impersonal Exchange: Theory and Policy of Contractual Registries. Chicago, IL: University of Chicago Press, 2012.

Ash, Robert and Richard L. Edmonds. "China's Land Resources, Environment and Agricultural Production.” China Quarterly 156 (1998): 836-879.

Baron, Jane B. "Rescuing the Bundle-of-Rights Metaphor in Property Law." University of Cincinnati Law Review 82 (2014): 57-101.

Binswanger, Hans and Mark Rosenzweig. "Behavioral and Material Determinations of Production Relations in Agriculture." Journal of Development Studies 22, 3 (1986): 503-539.

Bramall, Chris. "The Role of Decollectivisation in China's Agricultural Miracle, 1978-1990." Journal of Peasant Studies 20, 2 (1993): 271-295.

—. Sources of Chinese Economic Growth, 1978-1996. New York, NY: Oxford University Press, 2000.

- "Chinese Land Reform in Long-Run Perspective and in the Wider East Asian Context." Journal of Agrarian Change 4, 1/2 (2004): 107-141. 
Braverman, A vishay and J. Luis Guasch. "Rural Credit Markets and Institutions in Developing Countries: Lessons for Policy Analysis from Practice and Modem Theory." World Development 14, 10-11 (1986): 1253-1267.

Braverman, Avishay and J. Luis Guasch. "Institutional Analysis of Credit Cooperatives." In The Economic Theory of Agrarian Institutions, edited by Pranab Bardhan, pp. 341-353. Oxford, UK: Oxford University Press, 1991.

Brown, Lester. Who Will Feed China? Wake-Up Call for a Small Planet. New York, NY: Norton, 1995.

Carruthers, Ian and Roy Stoner. "Economic Aspects and Policy Issues in Groundwater Development.” Staff working paper No. 496. Washington, D.C.: World Bank, 1981. Available at wwwwds.worldbank.org/external/default/WDSContentServer/WDSP/IB/2003/08/19/0001 78830_98101903412355/Rendered/PDF/multiOpage.pdf. Accessed December 1, 2015.

Chang, Gordon. The Coming Collapse of China. New York, NY: Random House, 2001.

Chen, Yizi. "The Dawn for the Rural Area, the Hope for China: Report of a Survey on the Implementing of 'Baochan Daohu' in the Rural Area in Anhui Province." In Rural Area, Economics, and Society (in Chinese), edited by Institution of Rural Development Problems in China,33-53. Beijing, China: Zhishi chubanshe (Knowledge Publishing Press), 1985.

Cheng, Yuk-Shing and Shu-ki Tang. "Agricultural Land Reform in a Mixed System: The Chinese Experience of 1984-1994." China Information 10, 3/4 (1995/1996): 44-74.

Chow, Gregory C. and Kui-Wai Li. "China’s Economic Growth: 1952-2010.” Economic Development and Cultural Change 51, 1 (2002): 247-256.

Coase, R.H. "The Problem of Social Cost." Journal of Law and Economics 3 (October 1960): 144.

Constitution of the People's Republic of China. Revision of 2004. Available at http:// english.peopledaily.com.cn/constitution/constitution.html. Accessed December 27, 2011.

Dagan, Hanoch. "The Craft of Property." California Law Review 91 (2003) 1517-1532.

Demsetz, Harold. "Toward a Theory of Property Rights." American Economic Review 57, 2 (1967): 347-359.

- "The Structure of Ownership and the Theory of the Firm." Journal of Law and Economics 26, 2 (1983): 375-390.

—. "Toward a Theory of Property Rights II: The Competition Between Private and Collective Ownership." Journal of Legal Studies 31, 2 (2002): 653-672.

De Soto, Hernando. "The Other Path: The Invisible Revolution in the Third World." Fragile States. http://www.fragilestates.org/about/articles-and-publications/topics/causes-andcharacteristics/the-other-path-the-invisible-revolution-in-the-third-world/. Accessed May 25, 2016.

-.The Mystery of Capital: Why Capitalism Triumphs in the West and Fails Everywhere Else. London: Black Swan, 2000.

Dollar, David. "Poverty, Inequality, and Social Disparities during China's Economic Reform (June 1, 2007).” World Bank Policy Research Working Paper No. 4253. Available at http://ssrn.com/abstract=994077. Accessed December 1, 2015.

Donaldson, John. "Why Do Similar Areas Adopt Different Developmental Strategies? A Study of Two Puzzling Chinese Provinces.” Journal of Contemporary China 18, 60 (2009): 421-444.

Dong, Xiaoxuan. "Two-Tier Land Tenure System and Sustained Economic Growth in Post1978 Rural China.” World Development 24, 5 (1996): 915-928. 
Doshi, Pratik, Priyanka Jain, Q. Forrest Zhang and John A. Donaldson. "Farmer, Peasant, Agribusiness, and the State: Transformations in the Agrarian Society of India and China." Paper presented at the Joint Conference of the Association for Asian Studies and International Convention of Asia Scholars, Honolulu, Hawaii, USA, March/April 2011.

Editorial Board of China Agriculture Yearbook (EBCAY). Agricultural Yearbook of China, 1980, 1981, 1982, 1983, 1984. Beijing, China: Agricultural Press, 1980-1984.

Ehrenfeld, D.W. Conserving Life on Earth. New York, NY: Oxford University Press, 1972.

Feder, Gershon and Tongroj Onchan. "Land Ownership Security and Farm Investment in Thailand.” American Journal of Agricultural Economics 69, 2 (1989): 311-320.

Feder, Gershon, Lawrence Lau, Justin Lin and Xiaopeng Luo. "Agricultural Credit and Farm Performance in China." Journal of Comparative Economics 13, 4 (1989): 508-525.

Fewsmith, Joseph. Dilemmas of Reform in China: Political Conflict and Economic Debate. Armonk, NY: M.E. Sharpe, 1994.

_. "Tacking the Land Issue - Carefully." China Leadership Monitor 27 (2008): 1-8.

Fogel, Robert. “\$123,000,000,000,000: China’s Estimated Economy by 2040. Be Warned.” Foreign Policy January-February 2010.

Gordon, H. Scott. "The Economic Theory of a Common-Property Resource: The Fishery." Journal of Political Economy 62, 2 (1954): 124-142.

Guhan, Sanjivi. "Social Security Options for Developing Countries." International Labour Review 133, 1 (1994): 35-53.

Guo, Sujian. "The Ownership Reform in China: What Direction and How Far?" Journal of Contemporary China 12, 36 (2003): 553-573.

Hardin, Garrett. "The Tragedy of the Commons." Science 162, 3859 (1968): 1243-1248.

Harvey, David. Rebel Cities: From the Right to the City. London, New York: Verson, 2012.

Heilbroner, R. L. An Inquiry into the Human Prospect. New York: Norton, 1974.

Heller, Michael A. "The Boundaries of Private Property." Yale Law Journal 108 (1999): 1163. 1191.

Ho, Peter. "Who Owns China's Land? Policies, Property Rights, and Deliberate Institutional Ambiguity." China Quarterly 166 (2001): 394-421.

- Institutions in Transition: Land Ownership, Property Rights and Social Conflict in China. Oxford, UK: Oxford University Press, 2005.

—. "In Defense of Endogenous, Spontaneously Ordered Development: Institutional Functionalism and Chinese Property Rights." Journal of Peasant Studies 40, 6 (2013): 1087 1118.

Hodgson, Geoffrey M. “Editorial Introduction to 'Ownership' by A.M. Honoré (1961).” Journal of Institutional Economics 9, 2 (2013): 223-255.

Hodgson, Geoffrey M. and Kainan Huang. "Brakes on Chinese Development: Institutional Causes of a Growth Slowdown.” Journal of Economic Issues 47, 3 (2013): 599-622.

Hohfeld, Wesley. "Some Fundamental Legal Conceptions as Applied in Legal Reasoning." Yale Law Journal 23 (1913): 16-59.

_. "Fundamental Legal Conceptions as Applied in Judicial Reasoning." Yale Law Journal 26 (1917): 710-770.

Honoré, Antony M. "Ownership." In Oxford Essays in Jurisprudence, edited by Anthony G. Guest, pp. 107-147. Oxford, UK: Oxford University Press, 1961.

Hsu, Immanuel C.Y. The Rise of Modern China. Oxford, UK: Oxford University Press, 1990.

Jiang, Yuanming. "A Solid Answer to 'Who Will Feed China'." People's Daily Online,

November 1, 2014. Available at 
http://en.people.cn/200601/04/eng20060104_232860.html. Accessed September 14, 2015.

Jonh, Kay, "The Stakeholder Corporation.” In Stakeholder Capitalism, edited by Gavin Kelly, Dominic Kelly and Andrew Gamble, pp. 125-141. Basingstoke, UK: Macmillan, 1997.

Johnson, D. Gale. The People's Republic of China: 1978-1990. San Francisco, CA: ICS Press, 1990.

. "Rural China in Transition to a Market Economy." Chinese Rural Economy 5 (1993): 1620.

Johnson, Denise R. "Reflections of the Bundle of Right." Vermont Law Review 32, 9 (2007): 247-272.

Johnson, O.E.G. "Economic Analysis, the Legal Framework and Land Tenure Systems." Journal of Law and Economics 15, 1 (1972): 259-276.

Kelliher, Daniel. Peasant Power in China: The Era of Rural Reform. New Haven,CT: Yale University Press, 1992.

Krishna, Anirudh. "Escaping Poverty and Becoming Poor: Who Gains, Who Loses, and Why?" World Development 32, 1 (2004): 121-136.

Kornai, János. The Socialist System: The Political Economy of Communism. Princeton, NJ: Princeton University Press, 1992.

Kung, J.K. "Equal Entitlement versus Tenure Security under a Regime of Collective Property Rights: Peasants' Preference for Institutions in Post-reform Chinese Agriculture.” Journal of Comparative Economics 21, 2 (1995): 82-111.

"Common Property Rights and Land Reallocations in Rural China: Evidence from a Village Survey."” World Development 28, 4 (2000): 701-719.

Kung, J.K. and Shouying Liu. "Farmers' Preferences Regarding Ownership and Land Tenure in Post-Mao China: Unexpected Evidence from Eight Counties.” The China Journal 38(1997): 33-63.

Land Administration Law of the People's Republic of China (LALPRC). Revision of 2004. Available at http://www.npc.gov.cn/englishnpc/Law/2007-12/12/content_1383939.htm. Accessed at May 25, 2016.

Lardy, Nicholas R. Agriculture in China's Modern Economic Development. Cambridge, UK: Cambridge University Press, 1983.

Law of the People's Republic of China on Land Contract in Rural Areas (adopted at 2002). Available at http://www.npc.gov.cn/englishnpc/Law/2007-12/06/content_1382125.htm. Accessed at May 2005, 2015.

Lin, G.C.S. Developing China: Land, Politics and Social Conditions. London: Routledge, 2009.

Lin, G.C.S. and S.P.S Ho. "China's Land Resources and Land-Use Change: Insights from the 1996 Land Survey." Land Use Policy 20, 2 (2003): 87-107.

Lin, Justin Yifu. "The Household Responsibility System Reform in China: A Peasant's Institutional Choice.” American Journal of Agricultural Economy 69, 2 (1987): 410-415.

—. "The Household Responsibility System in China's Agricultural Reform." Economic Development and Cultural Change 36 (1988): 199-224.

—. "The Household Responsibility System Reform in China Rural Reform." In Agriculture and Governments in an Interdependent World: Proceedings of the XX International Conference of Agricultural Economists, edited by Allen Mauder and Alberto Valdes, pp. 453-462. Aldershot, UK: Dartmout, 1989.

"Rural Factor Markets in China: After the Household Responsibility System Reform." In Chinese Economic Policy: Economic Reform at Midstream, edited by Bruce. L. Reynolds and Iipyong J. Kim, pp. 169-203. New York, NY: Paragon House, 1989b. 
—. "The Household Responsibility System Reform and the Adoption of Hybrid Rice in China." Journal of Development Economics 36 (1991): 353-372.

—. "Rural Reforms and Agricultural Growth in China." American Economic Review 82, 1 (1992): 34-51.

Ma, Licheng and Lin Zhijun. "The Night of Xiaogang Village Shakes the Earth.” In Jiaofeng (Crossing Swords) (in Chinese), pp. 125-129. Beijing: Jin Ri Zhongguo Chubanshe, 1998. Magnier, Mark. "China Outlines Land Reform Plan.” Los Angeles Times, October 20, 2008. http://articles.latimes.com/2008/oct/20/world/fg-land20. Accessed at May 25, 2016. Marx, Karl. "The Civil War in France." In Marx-Engels Selected Works, by Karl Marx and Friedrich Engels, pp. 473-545. Moscow, Russia: Foreign Languages Publishing House, 1958.

—. Capital. Volume I. Translated by Samuel Moore and Edward Aveling. Moscow, Russia: Foreign Languages Publishing House, 1961.

McMillan, John, John Whalley and Lijing Zhu. "The Impact of China's Economic Reforms on Agricultural Productivity Growth." Journal of Political Economy 97, 4 (1989): 781-807.

Mead, Robert W. "A Revisionist View of Chinese Agricultural Productivity?" Contemporary Economic Policy 21, 1 (2003): 117-131.

Merrill, Thomas W. and Henry E. Smith. "What Happened to Property in Law and Economics?" Yale Law Journal 111 (2001): 357-398.

Mossoff, Adam. "The Use and Abuse of IP at the Birth of the Administrative State." University of Pennsylvania Law Review 157 (2009): 2001-2050.

Munzer, Stephen R. A Theory of Property. Cambridge, UK: Cambridge University Press, 1990.

Nolan, Peter. "China's Post-Mao Political Economy: A Puzzle." Contributions to Political Economy 12 (1993): 71-87.

- China at the Crossroads. Malden, MA: Polity Press, 2004.

North, Douglass. Structure and Change in Economic History. New York, NY: W.W. Norton, 1981.

- Institutions, Institutional Change and Economic Performance. New York, NY: Cambridge University Press, 1990.

—_. "The Role of Institutions in Economic Development." United Nations Economic

Commission for Europe, Discussion Paper Series. UN, No. 2003.2, October 2003.

-Understanding the Process of Institutional Change. Princeton, NJ: Princeton University Press, 2005.

North, Douglass and R.P. Thomas. The Rise of the Western World: A Bew Economic History. Cambridge, UK: Cambridge University Press, 1973.

North, Douglass and Berry R. Weingast. "Constitutions and Commitment: The Evolution of Institutions Governing Public Choice in Seventeenth-Century England.” Journal of Economic History 49, 4 (1989): 803-832.

Oi, Jean C. Rural China Takes Off: Institutional Foundations of Economic Reform. Berkeley, CA: University of California Press, 1999.

Ophuls, William. "Leviathan or Oblivion." In Toward a Steady State Economy, ed. H.E. Daly, pp. 215-230. San Francisco, CA: Freeman, 1973.

- Ecology and the Politics of Scarcity. San Francisco: W.H. Freeman and Company, 1977.

Organization for Economic Cooperation and Development (OECD). "China's Emergence as a Market Economy: Achievements and Challenges." OECD contribution to the China Development Forum, Beijing, China, March 20-21, 2011. Available at www.oecd.org/dataoecd/27/17/47408845.pdf. Accessed January 12, 2012. 
Ostrom, Elinor. Governing the Commons: The Evolution of Institutions for Collection Action. Cambridge, UK: Cambridge University Press. Political Economy of Institutions and Decisions, 1990.

—. "Beyond Markets and States: Polycentric Governance of Complex Economic Systems." American Economic Review 100, 3 (2010): 641-672.

Keijiro Otsuka, Hiroyuki Chuma and Yujiro Hayami. "Towards a General Theory of Land and Labor Contracts in Agrarian Economies." Journal of Economic Literature 30 (1992): 1965 2018. Palomar, Joyce. "Land Tenure Security as a Market Stimulator in China." Duke Journal of Comparative and International Law 12, 1/2 (2002): 7-74.

Park, Wooyeal and Kihyun Lee. "I Want To Be Expropriated! The Politics of Xiaochanquanfang Land Development in Suburban China." Journal of Contemporary China 21, 74 (2012): 266-268.

Pei, Minxin. China's Trapped Transition. Cambridge, MA: Harvard University Press, 2006.

Peng, Gong. "China Needs No Foreign Help to Feed Itself." New York Times, June 2, 2011.

Penner, J.E. "The 'Bundle of Rights' Picture of Property." University of California Law Review 43 (1996): 711-741.

- The Idea of Property in Law. Oxford, UK: Oxford University Press, 1997.

People's Daily, 28 January 28, 1988.

Posner, Richard. "Economic Analysis of Law." In Economic Foundation of Property Law, edited by Bruce A. Ackerman, pp. 259-263. Boston, MA: Little, Brown and Co., 1975.

Property Law of the People's Republic of China (2007). Available at http://www.npc.gov.cn/englishnpc/Law/2009-02/20/content 1471118.htm Accessed May 25, 2016.

Prosterman, R.L. and T.M. Hanstad. "China: A Fieldwork-Based Appraisal of the Household Responsibility System.” In Agrarian Reform and Grassroots Development, edited by R.L. Prosterman et al., pp. 103-138. London: Lynne Rienner Publishers, 1990.

Qin, Hui. "Nongmin diquan liulun." (Six Comments on Farmers' Land Rights.") Shehui Kexue Luntan (Tribune of Social Sciences) 9 (2007): 122-146.

Ravallion, Martin. "A Comparative Perspective on Poverty Reduction in Brazil, China, and India.” World Bank Policy Research Working Paper Series. SSRN, October 1, 2009. Available at http://ssrn.com/abstract=1492560. Accessed December 1, 2015.

"Are There Lessons for Africa from China's Success Against Poverty?" World Development 37, 2 (2009): 303-313.

Renda Fazhi Gongzuo Weiyuanhui (RFGW). Zhonghua Renmin Gongheguo Tudi Guanlifa Shiyi. (An Interpretation of the Land Administration Law of the People's Republic of China.) Beijing, China: Falü Chubanshe, 1998.

Righter, Rosemary. "The Fat Lady Sings in China's Opera of Reform.” Times of London, October 20, 2008.

Rural Sample Survey Office (RSSO). The Report of the General Results of China's Rural Social and Economic Survey. Report of the Policy Study Office of the Central Committee of the CCP and Ministry of Agriculture. Bejing, China: Zhongyangdangxiao Press, 1992.

Sargeson, Sally. "Villains, Victims and Aspiring Proprietors: Framing 'Land-Losing Villagers' in China's Strategies of Accumulation.” Journal of Contemporary China 21, 77 (2012): 757-777.

Sened, Itai. The Political Institution of Private Property. Cambridge, UK: Cambridge University Press, 1997.

Shirk, S.L. China: Fragile Superpower. Oxford, UK: Oxford University Press, 2007.

Sicular, Terry, Yue Ximing, Björn Gustafsson and Li Shi. "The Urban-Rural Income Gap and Inequality in China." Review of Income and Wealth 53, 1 (2007): 93-126. 
Sinn, Hans-Werner. "Common Property Resources, Storage Facilities, and Ownership Structures: A Cournot Model of the Oil Market.” Economica 51 (1984): 235-252.

Smith, R.J. "Resolving the Tragedy of the Commons by Creating Private Property in Wildlife." Cato Journal 1 (1981): 439-468.

Smill, Vaclay. "China’s Agricultural Land.” China Quarterly 158 (1999): 414-429.

Song, Zheng, Kjetil Storesletten and Fabrizio Zilibotti. "Growing Like China." American Economic Review 101, 1 (2011): 202-241.

Stanway, David. "Radical Reforms to Set China's Farmers Free." The Guardian, October 13, 2008.

Steiger, Otto, ed. Property Economics: Property Rights, Creditor's Money, and the Foundations of the Economy. Marburg, Germany: Metropolis, 2008.

Task Force of Rural Cooperative Economies (TFRCE). "A Survey of the Operation of China's Land Contract System and Cooperative Organizations." Problems in Agricultural Economy 11 (1993): 45-53.

Torstensson, Johan. "Property Rights and Economic Growth: An Empirical Study." Kyklos 47, 2 (1994): 231-247.

Wang, Haidong. “Agriculture at the Cross Roads.” Beijing Review (May 1-7, 1989): 24-25.

Wang, Huimin. "Dangqian Nongcun Tudi Chengbao Jingying Guanli de Xianzhuang ji Wenti." (The Present Situation and Problems facing the Management and Administration of Rural Land Lease.) Zhongguo Nongcun Guancha 5 (1998): 56-57.

Wang, Jing, Yongyi Chen, Xiaomei Shao and Yingui Chao. "Land-Use Changes and Policy Dimension Driving Forces in China: Present, Trend and Future." Land Use Policy 29, 4 (2012): 737-749.

Wang, Shaoguang and Angang Hu. The political Economy of Uneven Development: The Case of China. Armonk, London: M.E. Sharpe, 1999.

Welch, W.P. "The Political Feasibility of Full Ownership Property Rights: The Case of Pollution and Fisheries." Policy Sciences 16 (1983): 165-180.

Wen, Guanzhong James. "The Current Land Tenure and Its Impact on Long Term Performance of the Farming Sector: The Case of Modern China." Ph.D. diss. University of Chicago, 1989.

Whyte, Martin. "Social Trends in China: The Triumph of Inequality?" In Modernizing China: Post-Mao Reform and Development, edited by Arthur Doak Barnett and Ralph N. Clough, pp. 103-123. Boulder, Colo: Westview Press, 1986.

Wong, Edward. "China May Let Peasants Sell Rights to Farmland." New York Times, October 10, 2008. http://www.nytimes.com/2008/10/11/world/asia/11china.html? r=0. Accessed May 25, 2016.

World Bank. "China: Macroeconomic Stability and Industrial Growth under Decentralized Socialism.” Washington, D.C.: World Bank, 1990.

Wu, Jinglian. "Twenty Years' Development of the Theory of Reform." In Twenty Years of Economic Reform: In Retrospect and Prospect, edited by Zhang Zhuoyuan, Huang Fanzhang, and Li Guangan (in Chinese), pp. 1-20. Beijing, China: Zhongguo jihua chubanshe, 1998.

Wu, Tingmei. "A Necessary Medicine: The Investigation of 'Bangandaohu' at Xiaogang Brigade of Liyuan Commune in Fengyang County." In The History of Classical Agricultural Cooperation in Contemporary China, edited by Institution of Rural Cooperation System in Contemporary China (in Chinese), pp. 570-579. Beijing, China: Zhongguo nongye chubanshe (Chinese Agricultural Pressing), 2002.

Xu, Zhun. "The Political Economy of Decollectivization in China." Monthly Review 65, 1 (2013): 17-36. 
Yao, Shujie. "Economic Growth, Income Inequality and Poverty in China under Economic Reforms." Journal of Development Studies 35, 6 (1999): 104-130.

Zhang, Guangyou. "The Process of 'Dabaogan' in Xiaogang Village in Anhui Province.” In The History of Classical Agricultural Cooperation in Contemporary China, edited by Institution of Rural Cooperation System in Contemporary China (in Chinese), pp. 559-570. Beijing, China: Zhongguo nongye chubanshe (Chinese Agricultural Pressing), 2002.

Zhang, Linxiu, Scott Rozelle and Jikun Huang. "Off-Farm Jobs and On-Farm Work in Periods of Boom and Bust in Rural China." Journal of Comparative Economics 29, 3 (2001): 505-526.

Zhang, Qian Forrest and John Donaldson. "China's Agrarian Reform and the Privatization of Land: A Contrarian View.” Journal of Contemporary China 22, 80 (2013): 255-272.

Zheng, Lifei. "Wen Urges Protection for Farmer Rights, Stop to Land Grabs." Bloomberg Businessweek, December 28, 2011. Available at www.businessweek.com/news/2011-12-28/ wen-urges-protection-for farmer-rights-stop-to-land-grabs.html. Accessed December 29, 2011.

Zhou, Kate Xiao. How the Farmers Changed China: Power of the People. Boulder, CO: Westview Press, 1996.

Zhou, Qiren. "The Continuing Land Reform on the Mainland China." In China's Economic Reform: Analysis, Reflections and Prospects, edited by Dianging Xiu, Dingming Zhang, Francis T. Liu and Xin Zhang, pp. 127-138. Hongkong: Chinese University Press, 1991.

Zhu, Ling. Rural Reform and Peasant Income in China. London: Macmillan, 1991.

Zhu, Ling and Zhongyi Jiang. "From Brigade to Village Community: The Land Tenure System and Rural Development in China." Cambridge Journal of Economics 17, 4 (1993): 441-461. 